\title{
Responsibility of PT Telkom Towards Indihome Fiber Users Concerning Network Disruption According to Law Number 8 Of 1999 On Consumer Protection (Case Study: Pt Telkom Tanjung Balai Karimun)
}

\author{
Eno Dwi Puteri*, Syafrinaldi and Surizki Febrianto \\ Pascasarjana Ilmu Hukum, Universitas Islam Riau, 113, Jalan. Kaharuddin Nasution, Pekanbaru, Riau-28284, \\ Indonesia \\ *Corresponding author email: syafrinaldi@law.uir.ac.id
}

\begin{abstract}
The background of this study is the existence of an imbalance between Law Number 8 of 1999 on Consumer Protection and the Responsibilities of PT. Telkom Regional TanjungBalaiKarimun that occurs in the field related to the problem of slow and lack of internet connection which causes losses to Indihome Fiber users. The stipulations on consumer rights as well as obligations of business actors have clearly been regulated under Article 4 and 7 of Law Number 8 of 1999 on Consumer Protection. However, PT. Telkom Tanjung Peninsula Karimun area failed to fulfill its duties as stipulated under article 4 and article 7 of Law Number 8 of 1999. PT. Telkom failed to fulfill its obligation towards Indihome Fiber Customers. Furthermore, PT Telkom also failed to fulfill its responsibility regarding Internet Network Disruption due to errors and omissions caused by PT. Telkom TanjungBalaiKarimun area itself. Moreover, there is a lack of supervision and maintenance of the network that causes disadvantaged towards Indihome Fiber users and the slow handling of PT. Telkom in improving the network.
\end{abstract}

Keywords: PT Telkom, Indihome Fiber, Network Disruption

\section{INTRODUCTION}

Humans are social beings that are given the ability to communicate and delivering information in their daily life. This ability is not limited within the family line only but is broad[1]. Communication is a vital part of humans' lives. Communication is a process of exchanging information towards individuals through a certain system, either symbolically, using a certain signals and or actions and behavior[2].

Communications began ever since human existence in this earth. Along with the advancement of human civilization, ways of communicating were becoming advance as well[3]. Advancement in the field of technology has changed the world, whereas all sorts of information could be easily obtained within a short period of time. Communication is an essential aspect in order to fulfill humans needs.

In this advance era, communication is not only done through a direct meeting, the advancement of technology makes possible for people to communicate indirectly. By those advancements, telecommunication service provider holds a vital role in developing peoples' nation, giving an easier way for economic business activities as well as inter relationship.

The establishment of Law No 36 of 1999 on Telecommunication is considered as a form of support towards the advancement of communication. Similar to internet that is a part of long distance communication which could be done through a certain media ot communication tools that getting more advance.

Nowadays, business activity through internet is getting more attention. It is perceiveable from the amount of internet service provider that are spreading more and more such as internet café that provides internet with a low cost as a solution for the people to gain access to the internet[4]. This is understandable due to the fact that internet is not only a business of access but is considered to provide new ways of business activities[5], such as an online business providing various goods and or services through various platforms and websites to give an easy access for the customers. The use of telecommunication service as well as telecommunication networks as daily needs is a vital part for the society. The existence of needs towards 
telecommunication service and telecommunication networks has everything to do with the role of telecommunication provider which has duties to provide telecommunication service and networks.

One of many companies in the field of telecommunication in Indonesia is PT. Telkom Tbk as the biggest information and communication company in Indonesia[6], one of which is PT. Telkom TanjungBalaiKarimun. Products offered by PT Telkom that is widely used by the people is Indihome Fiber.

Indihome is a digital service using fiber optic technology in a form of cable made of micro glass or plastic, not bigger than a strand of hair which can be used to transmit signal from one place to another. This transmission came from the laser signal or LED (Light Emitting Diode) that has a larger bias index as to produce maximum speed.

Indihome is a Triple Play service which consists of the Internet with speeds ranging from $10 \mathrm{Mbps}$ to $300 \mathrm{Mbps}$, UseeTv cable is an interactive and hightech television service that is equipped with a full range of features as well local and long-distance landlines. Costumers who are in need of Indihome subscription is able to do so by registering directly through the Telkom Plaza office or througj an online application on a Mobile device by first downloading the My Indihome application or through the 147 contact center line.

Indihome service is offered to the public based on a standard contract for indihome service subscription. Under that agreement, each party, that is, the user or customer and the service provider namely PT. Telkom each has rights and obligations. However, PT. Telkom TanjungBalaiKarimun area does not implement a written subscription contract, using an excuse that each region has different provisions and policies.

PT Telkom holds a very influential role, especially in the field of provision of the Internet. Internet is the most prominent and very popular communication tool in the lives of Indonesian people today. Especially in big cities which of course the use of the internet network is increasingly widespread. In addition, the internet is also a platform of distribution of information and telecommunications that is very fast, precise, economical, and easy.

Indonesia also issued Law No. 8 of 1999 on Consumer Protection (Consumer Protection Act) which specifically regulates costumers and business actors. Legal protection for consumers in Indonesia over the use of goods and / or services provided by business actors is regulated under that exact law. The protection referred here is the protection of consumers whose rights and obligations are impaired by business actors. Consumers, in this case referred to as customers, of course, must have legal protection.

Article 4 of the Consumer Protection Act regulates consumers' rights; those are:

- To obtain comfort, security and safety in using or consuming the goods and/or service;

- To choose the goods and/or services and obtain Point $b$ the said goods and/or services in accordance with the promised conversion value and condition and warranty;

- To obtain correct, clear and honest information on the condition and warranty of the goods and/or services;

- To be heard in expressing opinion and complaints on the goods and/or services they use or consume;

- To obtain proper advocacy, protection and settlement in the consumer's protection dispute;

- To obtain consumer's training and education;

- To receive proper and honest and nondiscriminatory treatment or service;

- To obtain compensation, redress and/or substitution, if the goods and/or services received are not in accord with the agreement or not received as requested;

- To obtain rights as regulated in the other provisions of the law.

Obligations of business actors are also stipulated under article 7 of the Consumers Protection Act; those are:

- To act in good faith in conducting the business;

- To provide correct, clear end honest information with regard to the condition and warranty of the goods and/or services and provide explanation on the use, repair and maintenance;

- To treat and serve the consumers properly and honestly end non-discriminatively;

- To guarantee the goods and/or services produced and/or traded based on the prevailing quality standard provisions of the goods and/or services;

- To provide the opportunity to the consumers to test and/or try on certain goods and/or services and provide warranty and/or guarantee on the produced and/or traded goods;

- To provide compensation, redress and/or substitution for the damages caused by the use, consumption and application of the goods and/or services;

- To provide compensation, redress and/or substitution if the goods and/or services received or used do not accord with the agreement. 
The enactment of this Act aims to bring more awareness of all obligations that business actors convey[7]. To avoid negative consequences from the use of goods and/or services, the Act has imposed some restrictions[8]. However, the law is not able to evidently guarantee and ptotect those rights, many customers are still becoming the victims from the use of this goods and/or services.

With the internet disruption that occurred within PT. Telkom in TanjungBalaiKarimun, Riau Islands Province, of course, research is necessary in order to find out the cause of the network disruption of the Indihome Fiber Subscription product service in this area and what kind of damages shall be obtained by the Internet service user of the Indihome Fiber Subscription product.

Therefore, as explained under the background above, Author is intrigued to write a research titled "Responsibility of PT Telkom Towards Indihome Fiber Customers Concerning the Network Disruption According to Law No. 8 of 1999 on Consumer Protection (Case Study: PT Telkom TanjungBalaiKarimun)".

\section{RESEARCH METHODS}

This research is an observational research. To obtain the required data the author directly conducts research in the field using data collection tools in the form of questionnaires and interviews, while according to their nature this is classified as analytical descriptive research that presents a complete and detailed picture of the subject matter being studied. The object of this research is PT. Telkom towards Indihome Fiber Customers related to Internet Network Disruption according to Law
Number 8 of 1999 on Consumer Protection (Case Study of PT. Telkom TanjungBalaiKarimun).

The location where the author conducted this research includes the Office of PT. Telkom TanjungBalaiKarimun Area, located on JalanTeluk Air, the only location of PT. Telkom Regional TanjungBalaiKarimun. Population and samples are the most essential part to determine the object that is to be examined. Population is an entire unit or human (can also be a symptom, or event) that has the same characteristics[9]. These are populations being subjected to this research:

- Head of technician division of TanjungBalaiKarimun zone consisting of one population.

- Assistant Manager Operation and Maintenance of PT. Telkom TanjungBalaiKarimun consisting of one population.

- Indihome Fiber users who have complaints of network disruption in 2019 consisting of 132 populations.

Moreover, samples of this research consisted of:

- Head of technician division of TanjungBalaiKarimun zone consisting of one sample.

- Assistant Manager Operation and Maintenance PT. Telkom TanjungBalaiKarimun consisting of one sample.

- Indihome Fiber users who have complaints of network disruption in 2019 consisting of 39 populations.

More details on the samples of this study population can be seen in the following TABLE:

TABLE 1. Population and sample

\begin{tabular}{|c|c|c|c|c|}
\hline No & Name & Population & Sample & Percentage \\
\hline 1 & $\begin{array}{l}\text { Head of Technician of PT. Telkom } \\
\text { TanjungBalaiKarimun }\end{array}$ & 1 & 1 & $100 \%$ \\
\hline 2 & $\begin{array}{l}\text { Assistant Manager Operation and } \\
\text { Maintenance PT. Telkom } \\
\text { TanjungBalaiKarimun }\end{array}$ & 1 & 1 & $100 \%$ \\
\hline 3 & $\begin{array}{l}\text { Indihome Fiber users who have complaints of } \\
\text { network disruption in March } 2019\end{array}$ & 132 & 39 & $30 \%$ \\
\hline \multicolumn{2}{|r|}{ Amount } & 134 & 41 & - \\
\hline
\end{tabular}

Source: Field data, processed in 2019

\section{RESULT AND DISCUSSION}

Law functions as a tool to regulate public relations as law holds a nature and character that governs human behavior. Law was created to preserve rights and responsibilities concerning the problems of individuals, community groups, or an institution. One of the legal products in Indonesia is Law No. 8 of 1999 on Consumer Protection. Communication is a vital part in daily life, especially long distance communication that connects one person to another called telecommunications. The most widespread means of telecommunications used by the public is the Internet due to its fast and very sophisticated means of telecommunications. Like the people in TanjungBalaiKarimun who choose to subscribe to the internet for both business and communication purposes. As telecommunications is a very vital part for the community, government is obliged to provide 
it to the public, more especially the State-Owned Enterprise such as the PT. Telkom Indonesia, Tbk, which has many branches spreaded throughout cities in Indonesia such as PT. Telkom TanjungBalaiKarimun area.

Article 1 paragraph (e) of Law No. 36 of 1999 on Telecommunication (Telecommunication Act) stipulated that users mean individuals, legal institutions, government institutions that use telecommunications networks and or telecommunications services that are based on contracts. While article 3 on telecommunication subscription clause provides that users are those legal institutions or individuals that have signed the contract with PT Telkom to subscribe and to be held accounTABLE of all consequences rising out of the said contract.

One of the obligations of telecommunications operators stipulated under Telecommunication is that telecommunications operators must provide compensation for errors and/or negligence of telecommunications operators that cause losses, so that the injured parties have the right to file a compensation claims to the telecommunications operator unless the telecommunications operator can prove that the loss was not caused by an error and/or negligence. In addition to the Telecommunications Act, the government issued Consumer Protection Act which specifically regulates the rights and obligations of business actors as well as the rights and obligations of consumers.

The results of observations made by the author say that many customers using the Indihome Fiber Internet subscription package feel disadvantaged. Their rights as customers are not fulfilled due to the disruption of their internet network continuously. Even though they have notified complaints about the network disruptions, PT. Telkom TanjungBalaiKarimun area itself failed to handle these problems, which then leads to customers feeling disappointed and disadvantaged by the internet disruption. Moreover, the average customers are using the internet for business activities, office, school and daily communication needs, thereso this disruption is obstructing the customers interest.

These are the respondents' answers concerning the internet disruption of Indihome Fiber PT Telkom Tanjung Balai Karimun:

TABLE 2. Users experiencing slow and unavailability of internet connection

\begin{tabular}{|c|l|c|c|}
\hline No & Options & Numbers & Percentage (\%) \\
\hline 1 & Frequently & 18 & $46 \%$ \\
\hline 2 & Sometimes & 21 & $54 \%$ \\
\hline 3 & Never & - & - \\
\hline \multicolumn{2}{|c|}{ Amount } & 39 & $100 \%$ \\
\hline
\end{tabular}

Source: interview data of 2019

Based on these interview result with internet subscribers subscribed to PT. Telkom TanjungBalaiKarimun area on August $1^{\text {st }}, 2019,18$ out of 39 (46\%) subscribers of Indihome Fiber stated that they frequently experienced network disruption and slow connection. Whereas 21 out of 39 (54\%) customers have experienced network outages and slow connections. It can be concluded that network disruptions and slow connections on the Indihome Fiber Internet subscription network are very inhibiting and detrimental to customers.

According to the technician, this network disruption on indihome fiber is a problem occurred on the fiber network (optical or glass) which causes failure of function to the device or abnormal function causing discomfort or disruption to all and/or some of the services provided by PT. Telkom to its customers both in terms of physical and nonphysical disorders[10].

Customers who suffered losses from network outages and slow connections on the internet subscription are entitled to damage monet, it is indeed the responsibility of PT. Telkom TanjungBalaiKarimun area to its customers.

Furthermore, second questionnaire about losses is also available, those are:

TABLE 3. Customers feeling disadvantaged in case of outage or disruption

\begin{tabular}{|c|l|c|c|}
\hline No & \multicolumn{1}{|c|}{ Option } & Numbers & Percentage (\%) \\
\hline 1 & Yes & 39 & $100 \%$ \\
\hline 2 & Sometimes & - & - \\
\hline \multicolumn{2}{|c|}{ Amount } & 39 & $100 \%$ \\
\hline
\end{tabular}


Source: interview in 2019

Result of the interview said that $39(100 \%)$ of Indihome Fiber felt disadvantaged due to the interruption of the internet subscription, as the average customer used the internet subscription daily such as work and business purposes.

\section{CONCLUSION}

According to the researcher, PT. Telkom lacks responsibility in handling the matter of internet network disruption that occurred in PT. Telkom TanjungBalaiKarimun due to wrongdoings and omissions committed by PT. Telkom.

Lack of control and maintenance leads to disappointment of customers. The slow handling of this matter gives customers some disadvantaged. Furthermore, business actors have to pay attention to the lack of awareness towards the current regulation and therefore needs to pay more attention in fulfilling their duties as the telecommunication network provider, especially since PT. Telkom is a state owned enterprise. This problem appears to exist not only among the business actors, but the customers as well. Customers are not aware about their rights and obligations, customers are using their services without the proper knowledge of the rights and obligations of the provider and themselves as customers. In general, PT Telkom TanjungBalaiKarimun fulfilled its duty in terms of improving the network connection however failed to hand out compensation for the customers.

\section{REFERENCES}

[1] Judhariksawan, Pengantar Hukum Telekomunikasi,. 2005.

[2] Djoko Purwanto, Komunikasi Bisnis (Edisi Keempat), PT. Gelora Aksara Pratama, Jakarta,. 2011.

[3] Teddy Purnamirza, Sistem Telekomunikasi, Suska Press, Pekanbaru, 2008, hlm. 1. 2008.

[4] Kresno Aji,dkk, Buku Pintar Internet, PT. Elexmedia Komputindo, Jakarta,. 2000.

[5] Gouzali Saydam, Sistem Telekomunikasi di Indonesia, Alfabeta, Bandung, 2006, hlm.197. 2006.

[6] www.telkom.co.id, www.telkom.co.id diakses Pada Tanggal 23 Januari 2019. 2019.

[7] Gunawan Widjaja dan Ahmad Yani, Hukum Tentang Perlindungan Konsumen, Cet. Ke-3, Gramedia Pustaka Utama, Jakarta 2003, hlm. 2-3. 2003.

[8] Ahmadi Miru dan Sutaman Yodo, Hukum Perlindungan Konsumen, PT. Rajagrafindo Persada, Jakarta, 2004, hlm.63. 2004.
[9] Amiruddin Dan Zainal Asikin, Pengantar Metode Penelitian Hukum, Jakarta: PT. Raja Grafindo Persada, 2004, hlm. 95. 2004.

[10] Teknisi Telkom Akses di PT. Telkom daerah Tanjung Balai Karimun, Wawancara, 01 Agustus 2019. 2019. 